\title{
An examination of clients and project teams developing information requirements for the Asset Information Model (AIM)
}

\author{
D. Navendren, L. Mahdjoubi, M. Shelbourn \& J. Mason \\ Department of Architecture and the Built Environment, \\ University of the West of England, UK
}

\begin{abstract}
The client brief not being met by the final construction project could be due to a lack of clarity and collaboration causing substantial difficulties. As the final endproduct on a construction project is most heavily influenced by decisions made in the earliest stages, there lies an important necessity on clients clarifying their requirements collaboratively with the project team from the start. The impact of collaborative work from the genesis of a project is stressed especially with the implementation of Building Information Modelling (BIM) on projects, particularly with the UK government mandate to adopt BIM Level 2 by 2016 on all of its projects. The crux of enabling the realisation of BIM Level 2 lies in the clients and project team understanding how the Asset Information Model (AIM), 1 of the 8 Pillars of Level 2 BIM, is informed by the client requirements formed collaboratively with the team. This paper sets out the investigation of the collaborative development of information requirements for the AIM by the client and project team. This investigation is informed by the findings of a pilot study, involving 10 design firms, where qualitative semi-structured interviews were conducted to determine designers' perceptions, attitudes and experiences of BIM implementation, especially at the early stages of the design process. This paper reports the results of the pilot study outlining challenges faced by designers in key thematic areas. Team-oriented challenges highlighted collaboration and clarity of client requirements as key problematic areas.

Keywords: clients, project team, collaboration, Building Information Modelling (BIM), BIM Level 2, Asset Information Model (AIM), information requirements.
\end{abstract}




\section{Introduction}

Poor client leadership and team fragmentation have been heavily criticised as it leads to the client brief not being met, forming poorly informed decisions, delays, overspend, waste, disputes, inefficiencies, and overall dissatisfaction of the construction project [1-3]. The necessity for collaboration between the client and team from the genesis of the construction project was brought to light $[4,5]$. Wolstenholme et al. [6] stressed that implementing these recommendations for improvement will have long-lasting, positive effects on the construction industry and working practices.

A significant Government Construction Strategy was published in 2011 with the aim to enhance collaboration between the client and project team with the means of adopting Building Information Modeling (BIM) Level 2 on all of its projects by 2016 [7]. The Asset Information Model (AIM), 1 of the 8 Pillars of BIM Level 2, is required to be developed collaboratively by the client and project team [8]. This study sets out an examination of client and project teams developing information requirements for the Asset Information Model (AIM). The sections that follow encompass a background literature review on BIM Level 2, collaboration between the client and team from the start of a construction project, and the developing information requirements for the AIM. Subsequently a research framework intended to be adopted for this study, based on findings from a pilot study, will be proposed.

\section{Literature review}

\subsection{The importance of client and project team collaboration}

Porwal and Hewage [9] explain that clients have a pivotal role in adopting BIM as they are the driving force behind the facility, as the initiators, financiers, commissioners, owners, users or a combination of the previously mentioned [10]. Rowlinson [11] and Newcombe [12] explain that the industry usually typecasts clients into three categories: the public sector, the private sector and mixed; furthermore, clients can be grouped into uninformed, partially-informed, and wellinformed clients referring to the frequency of procuring projects from very rare, sometimes to very often respectively.

Kamara et al. [10] assert that the initial project expectations to the final project results are founded upon the client requirements, which need to be clearly defined from the outset. Appiah [13] agrees that clients need to initiate the construction process with a clarified understanding of their own expectations.

The client requirements feed into the work needed to be carried out throughout the project stages by the team; Brandon and Lu [14] support that the client and project team must work collaboratively to set up the initial brief with a clear project strategy and comprehensible specifications.

Crotty [15] concludes that BIM provides the necessary integrated platform, where the project specifications and brief are formed by the client and project team collaboratively from the earliest stages if a construction project. 


\subsection{BIM providing a platform for collaboration}

$\mathrm{BIM}$ is a means to managing construction projects through collaboration [16]. The UK BIM Task Group [17] explains that the movement to adopt BIM Level 2 by 2016 is to modernise the construction sector over the subsequent years. Similarly, Saxon [18] deduces that the construction industry has a strong basis for BIMdriven development, concluding that adopting BIM throughout the entire project lifecycle presents an opportunity for economic growth that can be realised by 2020 as the improvement in collaboration will lead to the reduction in time, cost and risk.

Azhar and Cochran [19] define BIM as a process where client requirements are used to build up a shared model that is "data-rich, object-oriented, intelligent and a parametric digital representation" of a construction project, utilised by all project stakeholders. An enormous benefit of BIM implementation is early collaborative decision-making between the client and project participants leading to numerous benefits including the following: greater integration between the various disciplines forming a construction team, a strong link between design decisions and costs, early virtual prototyping, simulations and improved visualisations, optimal asset performance, feedback of data, waste reduction in the construction process due to detailed asset and lifecycle planning, decreased errors in documents, reduction in capital costs, improved construction outcomes, higher predictability of performance [20-22].

To assist clients and the project team with correct BIM implementation from the outset of a construction project, publications such as the BIM execution plan were released to give guidance on how to formulate and communicate client specifications and purpose of the BIM models within tender documents for the designers and constructors [17]. The need for clarity of this process resulted in the 8 Pillars of BIM, which were constructed by the UK Government $[23,24]$.

\subsection{The 8 Pillars of BIM and developing information requirements for AIM}

Each of the 8 Pillars cohesively inform the implementation of BIM to its maximum benefits [23, 25]: PAS 1192-2:2013 is a publically available specification detailing how to digitally manage a project; PAS 1192-3:2014 is a specification about how to digitally manage an asset; PAS $1192: 5$ is another specification regarding information security; BS 1192-4 is a British Standard including information about effectively sharing information digitally; the BIM Protocol is a document that deciphers the important legal matters underpinning BIM; Government Soft Landings specifies a graduated handover of projects with targets to measure the progress; Digital Plan of Work is a cohesive plan of work that spans across all disciplines involved in a project; and Classification which clarifies how information and processes surrounding BIM are classified. BIM Level 2 lies in the clients and project team understanding how the 8 Pillars interact together. Below, Figure 1 defines the interactions of parts 2 and 3 . 


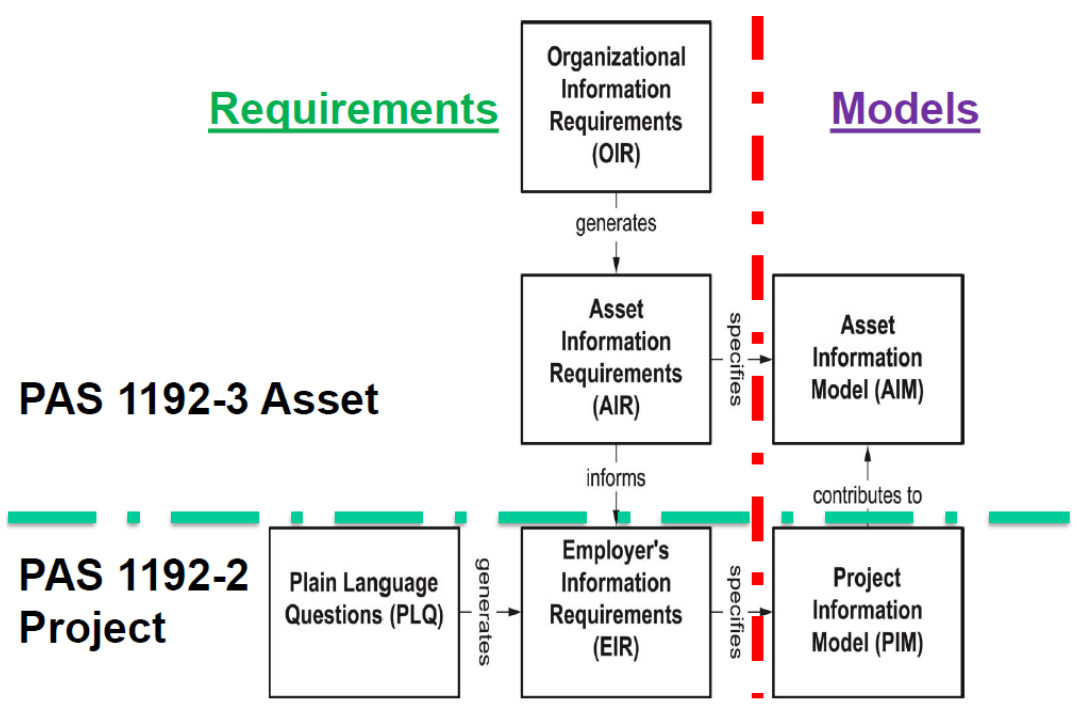

Figure 1: $\quad$ Relating PAS 1192-2:2013 and PAS 1192-3:2014 [26].

As presented in the above figure, all output models are substantiated by the Plain Language Questions (PLQ). Bryde et al. [27] explain how the Pillars of BIM interact: PAS 1192-2 informs the Project Information Model (PIM) during the construction phase and PAS 1192-3 respectively informs the Asset Information Model (AIM) for the operational phase. These models are verified against the Employer's Information Requirements and Organisational Information Requirements, which in turn constructs the Asset Information Requirements (AIRs). To fulfil the objectives within the PAS and BS documents, the classification scheme is compelled to be proficient in encapsulating all information and data within the Common Data Environment (CDE) across the Digital Plan of Works.

Birchall and Harris [26] encourage that the requirements informing the AIM in particular put forth the potential to eliminate waste from the project processes generating better project outcomes. The immense positive potential for the operators of the asset is generated as facilities management are engaged with the project from its genesis, promoting a relationship with the client from the earliest stage, thus a competitive edge is created for the facilities managers and supply chain as problems and risks are resolvable earlier on [28]. Moreover, Mohandesa et al. [8] support that the focus on the project itself and end users created by the information requirements specifying the AIM produces an overall improved endresult; it is evident that the development of the information requirements for AIM by the project team is an important factor that influences the entire project.

\subsection{Research gap}

Volk et al. [29] confirm that the BIM movement will progressively affect the construction industry and practices globally, increasing the need for research in 
this area to resolve any arising problems and provide guidance. Although BIM has been researched extensively over the past few years [30], there are research gaps needing to be filled.

Walker [31] describes that BIM implementation involves clients and project teams working collaboratively from the genesis of a construction project to produce information requirements that feed into the AIM, which critically impact the project end results. To implement BIM correctly, an all-inclusive decisionmaking process is needed where all team members are feeding into the project expectations and requirements $[10,32]$. The importance of client and project team collaboration from the earliest stages of a project has been stressed by many including Lew and Lentz [33], Mileham and Currie [34] and Uher and Loosemore [35]. Simultaneously, the importance of the project team developing information requirements to produce the AIM has been highlighted by several including, Birchall and Harris [26], Mohandesa et al. [8] and Arayici and Coates [28].

Despite research efforts, there is a research gap regarding the culmination of these important topics, scrutinising the collaborative development of information requirements for the AIM project by the client and project team from the earliest stages. This study will aim to fill this key research gap by proposing a research framework that is likely to include questionnaires and case studies.

\section{Proposed research framework}

This study adopts a combination of qualitative and quantitative approaches, resulting in a mixed method research approach; this is to obtain instrumental and intrinsic insight into the research topic as elucidated by Johnson et al. [36].

The mixed method incorporates quantitative research, which gives the opportunity to discover correlation, emerging patterns and causal relationships, but can be very general and doesn't allow for in-depth exploration of the social aspects [37]. This is counteracted by qualitative research which is based on perceptions, impressions, experience and trends offering the opportunity to produce results that have great depth but cannot apply extensively across the industry [38]. Undertaking the mixed method approach therefore gives opportunity for an in-depth exploration through qualitative research whilst producing results that also apply extensively across the industry due to the incorporation of quantitative research.

The case study approach was chosen as it facilitates a more in-depth form of research, which gives an opportunity to discover both the hard and soft aspects involved in process change and organisational relationships; Y in [39] accentuates the aspects of case studies being flexible, meticulous, systematic, narrow and indepth investigation, descriptive, focused on themes and able to provide more realistic responses than a statistic study - these are all supportive of the type of research that needs to be conducted.

The case study research will involve selecting projects and collecting data through documents, models and undertaking observations and semi-structured interviews to accumulate people's perceptions, ensuring that similar matters are discussed and collected data is akin, thus comparable. Patton [40] expresses that 
semi-structured interviews provide a greater focal point than a casual interview, but proffers autonomy and flexibility. Direct observations provide an overview of sampled situations therefore the researcher cannot participate and become immersed in the context [41]. As a direct observer of situations like client and project team meetings, Yin [39] advises that the researcher remains purely observant without participation, unobtrusive, unbiased and detached.

Yin [39] supports that case studies provide intensive conclusions with great depth, rather than extensive conclusions; therefore it is a strong form of exploratory research which will be undertaken for this study, seeking to investigate processes and collaboration between clients and project teams in the development of information requirements for the AIM. However due to the mixed method approach, the questionnaires will provide broad findings across the industry [42], uncovering patterns and correlations about the topic on a larger scale across the construction industry.

However, due to the nature of in-depth research studies, there are some inevitable limitations that must be considered at this stage. Case studies are found objectionable as the intense exposure is said to create biased findings however case studies are also most suited for capturing social processes and relationships [39]. To overcome the data being limited, the research will include two or three case studies rather than a single-case study in order to compare and contrast whilst capturing a wider scope of clients and project teams. Another limitation of the case study approach highlighted by Piekkari and Welch [43] is the potential lack of appropriate case studies. To avert this shortcoming, adequate preparation and prior-communication with professionals in the industry will be undertaken to ensure that pre-selected construction projects with good access are available for investigation, in the case that the questionnaires do not result in a selection of suitable case study options.

\subsection{Pilot study}

A pilot study was conducted where qualitative semi-structured interviews were adopted to collect data from design firms regarding the challenges of implementing BIM. The research strategy of interviews was chosen to explore the designers' perceptions, attitudes and experiences. For the pilot study, invitations were sent to design firms (i.e. architectural and engineering) in London, UK. From the 60 invitations to participate, 10 firms confirmed. Table 1 depicts the profiles of the firms and interview participants.

The participants' interviews were recorded, transcribed verbatim, crosschecked iteratively, coded with the use of QS NVivo 10 which led to the generation of themes, including team oriented challenges which are explored in the next section.

\subsection{Findings and discussion}

The analysis resulted in the classification of challenges faced by designers in key thematic areas including design-specific challenges, team-oriented challenges, project-related challenges, industry-related challenges, BIM-specific (technology) 
Table 1: Profiles of the 10 interview participants.

\begin{tabular}{|c|c|c|c|c|}
\hline Participant & Type of design firm & $\begin{array}{c}\text { Size of } \\
\text { firm* }\end{array}$ & $\begin{array}{c}\text { Firm's BIM } \\
\text { usage } \\
\text { experience }\end{array}$ & $\begin{array}{c}\text { Role of participant } \\
\text { with firm }\end{array}$ \\
\hline A & Engineering design & Large & 7 years & $\begin{array}{c}\text { Structural CAD } \\
\text { technician }\end{array}$ \\
\hline B & $\begin{array}{c}\text { Architectural and } \\
\text { engineering }\end{array}$ & Large & 7 years & $\begin{array}{c}\text { Digital design } \\
\text { representative }\end{array}$ \\
\hline D & Transport systems & Large & None & Structural engineer \\
\hline E & $\begin{array}{c}\text { Architectural and } \\
\text { engineering }\end{array}$ & Large & 9 years & $\begin{array}{c}\text { Applications } \\
\text { administrator and } \\
\text { BIM manager }\end{array}$ \\
\hline F & $\begin{array}{c}\text { Engineering } \\
\text { services, facility } \\
\text { management and } \\
\text { energy } \\
\text { management }\end{array}$ & Large & 12 years & $\begin{array}{c}\text { Architect } \\
\text { Engineering and }\end{array}$ \\
\hline G & Architectural & Large & None & $\begin{array}{c}\text { CAD and design } \\
\text { manager }\end{array}$ \\
\hline H & Architectural & Large & 2 years & BIM manager \\
\hline I & $\begin{array}{c}\text { Architectural and } \\
\text { interior design }\end{array}$ & Medium & 0.5 years & $\begin{array}{c}\text { BIM manager and } \\
\text { design team leader }\end{array}$ \\
\hline Architectural & Small & 1 year & Architect \\
\hline
\end{tabular}

*Firm size: Micro $<10$ employees, Small $<50$ employees, Medium $<250$ employees, and Large $\geq 250$ employees [44].

challenges and BIM cost challenges. The team-oriented challenges, highlighted by the designers, concerned working with other project participants. The teamoriented challenges included: a lack of understanding by clients regarding the brief, specifications and requirements for the BIM model as well as a lack of collaborative work amongst the team from early design stages.

Participant D commented that "the clients need to be further educated on BIM so that they know what to expect, but currently they don't understand enough" whilst Participant I was concerned regarding collaboration that "some clients have no specific requirements for models used for facilities management".

When discussing ways of addressing these challenges, Participant $F$ responded that "clients need to understand what they want and need from the BIM model and what benefits and pitfalls are involved within the different routes and specifications. There are a lot of client groups out there which are very up-todate." Furthermore Participant B suggested that clients ought to increase clarity, collaboration and communication, as "the standards out there need to be pushed by the client. The client must specify their requirements and that would take all 
the ambiguity out of it. "Within literature, similar issues have been explored where client uncertainty has been noted by Cabinet Office [7].

The challenges faced by designers regarding BIM implementation forms the basis for further research to discover the means of overcoming the challenges. Leading from these findings regarding the need for clarity and collaboration between the client and team, the proposed research strategy for this study was developed. As the development of information requirements for the AIM should be done collaboratively by the client and the team from the start of the construction project, the proposed study will focus on this area.

The contribution of this study will be an output of the identification of criteria for the collaborative development of information requirements for the AIM by clients and project teams from the earliest stages of a construction project, the key challenges and how to overcome them. A by-product from this is the development of a briefing guide for clients and project teams alike, providing advice and insight on good and bad practice with a matrix of recommendations and criteria for the development of information requirements for the AIM from the earliest project stages. This can provide guidance for all project team members adopting BIM; advice for clients and project teams developing information requirements for the AIM; and knowledge that can be utilised by various stakeholders from the government, industry and university teachers and students delivering and learning material related to the topic.

\section{Conclusion}

The need to manage complex information within a project throughout its different stages handled by the client and project team, calls for a collaborative platform [44]. The UK Government recognised this need and mandated the adoption of BIM Level 2 by 2016 to manage project information collaboratively and simultaneously resolve problems ingrained within the industry [45]. The previously conducted pilot study confirms that clarity of the client brief and project team collaboration from the genesis of the project is necessary to implement BIM correctly and mitigate the current challenges being faced by project team disciplines.

The collaboration between the client and project team is pivotal in the development of Information Requirements that feed into the AIM, 1 of the 8 Pillars of BIM Level 2 [8]. The study proposes a research strategy of questionnaires followed by case studies to examine client and project teams developing Information Requirements for the AIM from the earliest stages of a construction project.

\section{References}

[1] Egan, J., Rethinking Construction: The Report of the Construction Task Force, HMSO: London, 1998. 
[2] Larson, E., Partnering on construction projects: a study of the relationship between partnering activities and project success. Engineering Management, IEEE Transactions on, 44(2), pp. 188-195, 1997.

[3] Latham, M., Constructing the Team: Final Report of the Government/Industry Review of Procurement and Contractual Arrangements in the UK Construction Industry, HMSO: London, 1994.

[4] Boyd, D. \& Chinyio, E., Understanding the Construction Client, Blackwell Publishing: London, 2008.

[5] Vaaland, T. I., Improving project collaboration: start with the conflicts. International Journal of Project Management, 22(6), pp. 447-454, 2004.

[6] Wolstenholme, A., Austin, S. A., Bairstow, M., Blumenthal, A., Lorimer, J., McGuckin, S., Jones, S. R., Ward, D., Whysall, D., Le Grand, Z., Guthrie, W. \& Davies, R. (2009) Never waste a good crisis: A review of Progress since Rethinking Construction and Thoughts for Our Future, Constructing Excellence: London, 2009.

[7] Cabinet Office, Government construction strategy, 2011, http:/www.cabinetoffice.gov.uk/sites/default/files/resources/GovernmentConstruction-Strategy.pdf

[8] Mohandesa, S. R., Hamidb, A. R. A., \& Sadeghic, H., Exploiting Building Information Modeling Throughout the Whole Lifecycle of Construction Projects. Journal of Basic and Applied Scientific Research, 4(9), pp. 16-27, 2014.

[9] Porwal, A. \& Hewage, K. N., Building Information Modeling (BIM) partnering framework for public construction projects. Automation in Construction, 31, pp. 204-214, 2013.

[10] Kamara, J. M., Anuma, C. J. \& Evbuomwan, N. F. O., Capturing Client Requirements in Construction Projects, Thomas Telford: London, 2002.

[11] Rowlinson, S., A definition of procurement systems, In: Rowlinson, S. and McDermott, P., ed. Procurement Systems: A Guide to Best Practice in Construction, E and FN Spon: London, 1999.

[12] Newcombe, R., Procurement Paths - A Power Paradigm, In: S. M. Rowlinson, ed. East Meets West, Proceedings of CIB W92 Procurement Systems Symposium, Department of Surveying, The University of Hong Kong, December, pp. 243-250, 1994.

[13] Appiah, S. Y., Procurement of Construction Projects: Simple Theory Complex Practice, In: Lockren, P. and Malpass, M., ed. The Nottingham Trent University Research Practice Course Annual Student Conference 2010, pp. 26-30, 2010.

[14] Brandon, P. S. \& Lu, S., Clients Driving Innovation, Blackwell: West Sussex, 2009.

[15] Crotty, R., The Impact of Building Information Modelling: Transforming Construction. SPON Press: Oxon, 2012.

[16] Sebastian, R., \& van Berlo, L., Tool for benchmarking BIM performance of design, engineering and construction firms in the Netherlands. Architectural Engineering and Design Management, 6(4), pp. 254-263, 2010. 
178 Building Information Modelling (BIM) in Design, Construction and Operations

[17] BIM Task Group, Welcome to the BIM Task Group Website, 2013, http://www.bimtaskgroup.org/

[18] Saxon, R., Two Missing Pieces in the BIM Puzzle, Building, 2014, http://www.building.co.uk/two-missing-pieces-in-the-bim-puzzle/ 5066572.article

[19] Azhar, S. \& Cochran, S., Current status of building information modeling (BIM) adoptability in the US electrical construction industry. The fifth international conference on construction in the 21st century "Collaboration and Integration in Engineering, Management and Technology”, p. 1387. 2009.

[20] Arensman, D. B. \& Ozbek, M. E., Building Information Modeling and Potential Legal Issues. International Journal of Construction Education and Research, 8(2), pp.146-156, 2012.

[21] Newton, K. L. \& Chileshe, N., Awareness, Usage and Benefits of BIM Adoption - The Case of South Australian Construction Organizations. Proceedings 28th Annual ARCOM Conference, 3-5 September 2012, Edinburgh, UK, pp. 3-12, 2012.

[22] Philp, D., Level 2 BIM Ready, Steady, Go by the Head of BIM Implementation for the Cabinet Office, BIM Task Group: Cardiff, 2012.

[23] The B1M Limited, Pillar 3: PAS 1192-4 (COBie) The 8 Pillars of BIM Level 2, 2015, http://www.theb1m.com/video/pillar-3-pas-1192-4-cobie-the-8pillars-of-bim-level-2

[24] Kreider, R. G., An Ontology of the Uses of Building Information Modeling. The Pennsylvania State University, 2013.

[25] Fenby-Taylor, H., BIM Level 2... I can tell you what it is!! Landscape BIM, 2014, http://landscapebim.blogspot.co.uk/2014/09/bim-level-2-i-can-tellyou-what-it-is.html

[26] Birchall, S. \& Harris, J., An Introduction to BIM, 2014, http://www.slideshare.net/BSRIA/bim-introduction

[27] Bryde, D., Broquetas, M. \& Volm, J. M., The project benefits of Building Information Modelling (BIM). International Journal of Project Management, 31(7), pp. 971-980, 2013.

[28] Arayici, Y. \& Coates, P., Operational knowledge for BIM adoption and implementation for lean efficiency gains. Journal of Entrepreneurship and Innovation Management, 1(2), pp. 1-20, 2013.

[29] Volk, R., Stengel, J. \& Schultmann, F., Building Information Modeling (BIM) for existing buildings - Literature review and future needs. Automation in Construction, 38, pp. 109-127, 2014.

[30] Eastman, C., Teicholz, P., Sacks, R. \& Liston, K., BIM Handbook: A Guide to Building Information Modeling for Owners, Managers, Designers, Engineers and Contractors, Wiley: Hoboken, 2011.

[31] Walker, A., Project management in construction. John Wiley \& Sons: West Sussex, 2015.

[32] Zimina, D., Ballard, G., \& Pasquire, C., Target value design: using collaboration and a lean approach to reduce construction cost. Construction Management and Economics, 30(5), pp. 383-398, 2012. 
[33] Lew, J.J. \& Lentz, T.J., Designing for Safety - Applications for the Construction Industry. Proceedings of CIB World Building Congress W099, Salford, UK, 2010.

[34] Mileham, A. R. \& Currie, C. G., Conceptual Cost Information as an Aid to the Designer. International Operation: Crossing Borders in Manufacturing and Service, pp. 199-124, 1992.

[35] Uher, T. E. \& Loosemore, M., Essentials of Construction Project Management, University of New South Wales Ltd: Sydney, 2004.

[36] Johnson, R. B., Onwuegbuzie, A. J. \& Turner, L. A., Toward a Definition of Mixed Methods Research. Journal of Mixed Methods Research, 1(2), pp. 112-133, 2007.

[37] Vogt, W. P., Quantitative research methods for professionals in education and other fields, Allyn \& Bacon: New York, 2006.

[38] Patton, M. Q., Qualitative Evaluation and Research Methods, Sage Publications, Inc: Newbury Park CA, 1990.

[39] Yin, R. K., Case Study Research: Design and Methods, Sage Publications Ltd: California, 2013.

[40] Patton, M. Q., Qualitative Research and Evaluation Methods, Sage Publications, Inc.: California, 2002.

[41] Ary, D., Jacobs, L., Sorensen, C., \& Walker, D., Introduction to Research in Education. Wadsworth: Cengage Learning, 2013.

[42] Biggam, J., Succeeding with your Master's Dissertation: A Step by Step Handbook, Open University Press: New York, 2011.

[43] Piekkari, R. \& Welch, C., Rethinking the case study in international business and management research, Edward Elgar Publishing: Cheltenham, 2011.

[44] European Commission, The new SME definition, 2005, http://ec.europa.eu/ enterprise/policies/sme/facts-figures-analysis/sme-definition/

[45] Arayici, Y., Coates, P., Koskela, L., Kagioglou, M., Usher, C., \& O’Reilly, K., Technology adoption in the BIM implementation for lean architectural practice. Automation in Construction, 20(2), pp. 189-195, 2011.

[46] Construction Industry Council, 2011, Government Construction Strategy, http://www.cic.org.uk/gcs/GovernmentConstructionStrategy.pdf 